\title{
PEMBATASAN FRASA PERUBAHAN KESEKIAN KALI PADA PERUMUSAN JUDUL UNDANG-UNDANG: TELAAH TERHADAP UNDANG-UNDANG PERPAJAKAN
}

\author{
Evie Rachmawati Nur Ariyanti \\ Fakultas Hukum Universitas YARSI \\ Email : evie.rachmawati@yarsi.ac.id
}

\begin{abstract}
Lawmakers can amend a regulation when it is no longer compatible to the current situation. However, from the numerous amendments made in three tax laws, there has confusion among law practitioners when referring to which law and what tittle to use. This paper is juridical-normative research which examines secondary data collected from literature study. When a regulation has been through numerous amendments, which might put the practitioners on the spot when they have to refer a particular regulation, it is necessary that the referred regulation be re-announced based on the latest version, mentioning the amended parts. Thus, the law which particularly regulates the enactment of laws should limit the use of phrase "The First / Second / Third /etc Amendment", especially when formulating a tittle of a law.
\end{abstract}

Keywords : Limiting, Amendment, Law

\begin{abstract}
Abstrak
Perubahan suatu undang-undang dapat dilakukan terhadap ketentuan-ketentuan yang tidak sesuai lagi dengan situasi atau kondisi yang berlaku dalam masyarakat. Namun demikian, dari beberapa kali perubahan terhadap ketiga undang-undang di bidang perpajakan, telah menimbulkan kebingungan dari pengguna undang-undang atas pengaturan mana yang masih digunakan dan penyebutan terhadap undang-undang tersebut. Penelitian ini merupakan penelitian yuridis normatif, yaitu penelitian terhadap data sekunder yang datanya diperoleh melalui studi kepustakaan. Apabila suatu undang-undang telah sering mengalami perubahan hingga menyulitkan pengguna undang-undang tersebut, sebaiknya peraturan tersebut diumumkan kembali menurut bunyi yang baru sesuai dengan perubahan-perubahan yang telah dilakukan dengan mengadakan penyesuaian. Untuk itu dalam undang-undang tentang pembentukan peraturan perundang-undangan dapat dilakukan pengaturan tentang pembatasan frasa perubahan kesekian kali pada perumusan judul suatu undang-undang.
\end{abstract}

Kata kunci : Pembatasan, Perubahan, Undang-Undang,

\section{PENDAHULUAN}

Indonesia sebagai negara yang berpegang teguh pada Pancasila dan Undang-Undang Dasar Negara Republik Indonesia Tahun 1945, harus senantiasa 
mendasarkan segala aspek kehidupan dalam bidang kemasyarakatan, kebangsaan, dan kenegaraan termasuk pemerintahannya pada hukum. Hal ini ditegaskan dengan Pasal 1 Ayat (3) Undang-Undang Dasar Negara Republik Indonesia Tahun 1945 yang menyatakan bahwa Indonesia adalah negara hukum.

Hukum itu sendiri bagi sebagian besar sarjana hukum didefinisikan sebagai himpunan peraturan-peraturan hukum yang mengatur kegiatan kehidupan kehidupan manusia yang dapat dipaksakan pelaksanaannya. Sebagian besar sarjana hukum (hakim, jaksa, dosen, pengacara dan sebagainya) pada umumnya dihadapkan pada peristiwa konflik yang memerlukan pemecahan suatu konflik. Untuk itu memecahkan peristiwa atau konflik itu dicarikan norma atau hukumnya dan hukumnya terdapat dalam himpunan peraturan-peraturan hukum. Oleh karena itu, tidak mengherankan kalau Noll mengatakan bahwa ilmu hukum itu merupakan ilmu peradilan (rechtspraakwetenschap). ${ }^{1}$

Sekarang ini lahir ilmu hukum baru di samping ilmu peradilan, yaitu ilmu hukum yang merupakan ilmu pembentukan undang-undang (wetgevingswetenschap). Di sini studi hukum itu dilihat dari kaca mata pembentuk undang-undang. Masalahnya di sini bukannya bagaimana memecahkan konflik individual yang konkrit dengan menerapkan normanya tetapi bagaimana merumuskan atau membentuk peraturan hukum atau mengatur kehidupan manusia atau masyarakat untuk waktu mendatang dalam kurun waktu tertentu. $^{2}$ Merupakan suatu kenyataan bahwa dalam hidup bermasyarakat diperlukan aturan-aturan yang bersifat umum. Betapapun setiap kepentingan yang ada di dalam masyarakat dipertimbangkan untuk dituangkan di dalam aturan yang bersifat umum agar kepentingan-kepentingan itu dilindungi dan sedemokratis apapun kehidupan bernegara dan bermasyarakat suatu bangsa, tidaklah mungkin aturan-aturan itu dapat mengakomodasi semua kepentingan tersebut. ${ }^{3}$

Undang-undang tentang pembentukan peraturan perundang-undangan merupakan pelaksanaan Pasal 22 A Undang-Undang Dasar Negara Republik

\footnotetext{
${ }^{1}$ Sudikno Mertokusumo, Penemuan Hukum, (Yogyakarta: Universitas Atmajaya: 2010), hal. 18

${ }^{2}$ Ibid, hal. 19

${ }^{3}$ Peter Mahmud Marzuki, Pengantar Ilmu Hukum, (Jakarta: Kencana Prenada Media Grup, 2009), hal. 157
} 
Indonesia Tahun 1945 yang menegaskan bahwa ketentuan lebih lanjut mengenai tata cara pembentukan undang-undang diatur lebih lanjut dengan undang-undang. Perintah tersebut telah dilaksanakan yakni dengan diberlakukannya Undang-Undang Nomor 10 Tahun 2004 tentang Pembentukan Peraturan Perundang-undangan yang kemudian dalam perkembangannya diganti dengan Undang-Undang Nomor 12 Tahun 2011 Tentang Pembentukan Peraturan Perundang-undangan.

Namun demikian, dari beberapa penyempurnaan yang dilakukan terhadap UU tentang pembentukan peraturan perundang-undangan, tidak ada pembatasan frasa perubahan kesekian kali pada judul suatu undang-undang. Akibatnya, timbul kebingungan dari pengguna undang-undang atas pengaturan mana yang masih digunakan dan penyebutan terhadap suatu undang-undang. Kebetulan hal ini terjadi pada undang-undang di bidang perpajakan. Jika diteliti, terdapat 3 (tiga) undang-undang yang telah direvisi sampai dengan perubahan ketiga bahkan ada yang sampai dengan perubahan keempat yang dapat diketahui dari judul undang-undang tersebut. Tentunya hal ini akan berpengaruh terhadap para pihak yang berkaitan dengan peraturan tersebut.

Sejak tahun 1983, hukum nasional di bidang perpajakan telah menunjukkan jati dirinya karena telah memiliki hukum (baca: undang-undang) sendiri dengan tidak lagi menggunakan perundang-undangan peninggalan kolonial Belanda. Politik hukum yang dibangun bangsa Indonesia khususnya di bidang perpajakan paling tidak telah menunjukkan adanya proses pembangunan hukum yang berintikan pada pembentukan dan pembaruan terhadap materi-materi hukum agar dapat sesuai dengan kebutuhan yang dihadapi bangsa Indonesia, serta adanya pelaksanaan dan penegasan fungsi lembaga dan pembinaan para penegak hukum terhadap proses penerapan UU yang ada. ${ }^{4}$ Oleh karena itu, berdasarkan uraian yang dikemukakan, akan dikaji tentang bagaimanakah seharusnya pengaturan terhadap perubahan atas suatu undang-undang dengan menelaah dari undang-undang perpajakan Indonesia.

\footnotetext{
${ }^{4}$ Wirawan B. Ilyas dan Richard Burton, Hukum Pajak Edisi 5, (Jakarta: Salemba Empat, 2011), hal. 16
} 


\section{METODE PENELITIAN}

Dalam penelitian pada umumnya dibedakan antara data yang diperoleh langsung dari masyarakat dan dari bahan-bahan pustaka. Bahan yang diperoleh langsung dari masyarakat dinamakan data primer (atau data kasar), sedangkan yang diperoleh dari bahan pustaka lazimnya dinamakan data sekunder. ${ }^{5}$ Penelitian ini merupakan penelitian yuridis normatif, yaitu penelitian terhadap data sekunder yang datanya diperoleh melalui studi kepustakaan dan selanjutnya dianalisis secara kualitatif.

\section{PEMBAHASAN}

\section{Pembentukan Undang-Undang di Indonesia}

Untuk mewujudkan negara hukum diperlukan tatanan yang tertib antara lain di bidang pembentukan peraturan perundang-undangan. Tertib pembentukan peraturan peraturan perundang-undangan harus dirintis sejak saat perencanaan sampai dengan pengundang-undangannya. Oleh karena itu, untuk membentuk peraturan perundang-undangan yang baik diperlukan berbagai persyaratan yang berkaitan dengan sistem, asas, tata cara penyiapan dan pembahasan, teknik penyusunan maupun pemberlakuannya.

Terdapat berbagai macam ketentuan yang berkaitan dengan pembentukan peraturan perundang-undangan termasuk teknik penyusunan peraturan perundang-undangan diatur secara tumpang tindih baik peraturan yang berasal dari masa kolonial maupun yang dibuat setelah Indonesia merdeka, yaitu: ${ }^{6}$

1. Algemeene Bepalingen van Wetgeving voor Indonesie, yang disingkat $A B$ (Stb. 1874:23) yang mengatur ketentuan-ketentuan umum peraturan perundang-undangan. Sepanjang mengenai pembentukan peraturan perundang-undangan, ketentuan $\mathrm{AB}$ tersebut tidak lagi berlaku secara utuh karena telah diatur dalam peraturan perundang-undangan nasional.

\footnotetext{
${ }^{5}$ Soerjono Soekanto dan Sri Mamudji, Penelitian Hukum Normatif Suatu Tinjauan Singkat, (Jakarta: PT Raja Grafindo Persada, 2001), hal. 12

${ }^{6}$ Indonesia, Undang-Undang Pembentukan Peraturan Perundang-undangan, UU No. 10 Tahun 2004, Penjelasan
} 
2. Undang-Undang Nomor 1 tahun 1950 tentang Peraturan tentang jenis dan Bentuk Peraturan yang Dikeluarkan Oleh Pemerintah Pusat. Undang-Undang ini merupakan Undang-Undang dari Negara Bagian Republik Indonesia Yogyakarta.

3. Undang-Undang Nomor 2 tahun 1930 tentang Menetapkan Undang-Undang Darurat tentang Penerbitan Lembaran Negara Republik Indonesia Serikat dan tentang Mengeluarkan, Mengumumkan, dan Mulai Berlakunya UndangUndang Federal dari Peraturan Pemerintah sebagai Undang-Undang Federal.

4. Selain Undang-Undang tersebut terdapat pula ketentuan:

a. Peraturan Pemerintah Nomor 1 Tahun 1945 tentang Pengumuman dan Mulai berlakunya Undang-Undang dan Peraturan Pemerintah;

b. Keputusan Presiden Republik Indonesia Nomor 234 tahun 1960 tentang Pengembalian Seksi Pengundangan Lembaran Negara dari Departemen Kehakiman ke Sekretariat Negara;

c. Instruksi Presiden Republik Indonesia Nomor 15 tahun 1970 tentang Tata Cara Mempersiapkan Rancangan Undang-undang dan Rancangan Peratiran Pemerintah Republik Indonesia;

d. Keputusan Presiden Republik Indonesia Nomor 44 Tahun 1999 tentang Teknik Penyusunan Peraturan Perundang-undangan dan Bentuk Rancangan Undang-undang, Rancangan Peraturan pemerintah dan Rancangan Keputusan Presiden;

5. Di lingkungan Dewan Perwakilan Rakyat dan Dewan Perwakilan Rakyat Daerah, berlaku peraturan tata tertib yang mengatur antara lain mengenai tata cara pembahasan rancangan undang-undang dan rancangan peraturan daerah serta pengajuan dan pembahasan rancangan undang-undang dan rancangan peraturan daerah usul inisiatif Dewan Perwakilan Rakyat atau Dewan Perwakilan Rakyat Daerah.

Setelah mengalami perubahan secara bertahap sebanyak empat kali, yaitu pada tahun 1999, 2002, 2003, dan 2004, materi UUD 1945 yang asli telah mengalami perubahan secara besar-besaran. Dari sisi substantif, perubahan yang 
terjadi atas UUD 1945 telah menjadikan konstitusi proklamasi tersebut menjadi konstitusi yang baru sama sekali, hanya saja namanya tetap dipertahankan sebagai Undang-Undang Dasar Negara Republik Indonesia Tahun 1945. Adapun dari sisi kuantitatif, UUD 1945 sebelum perubahan hanya terdiri atas 71 butir ketentuan. Namun setelah perubahan, UUD 1945 memiliki 199 butir ketentuan atau dengan kata lain telah bertambah hampir 200\% jumlahnya. Dari keseluruhan 199 butir ketentuan tersebut, naskah UUD 1945 yang masih asli dan tidak mengalami perubahan hanya 25 butir ketentuan (12\%), sedangkan selebihnya sebanyak 174 butir ketentuan (88\%) merupakan materi yang baru sama sekali. Dengan demikian dapat disimpulkan bahwa pokok-pokok pikiran yang terkandung dalam rumusan pasal-pasal UUD 1945 pasca perubahan tersebut, benar-benar berbeda dari pokok pikiran yang terkandung dalam naskah asli ketika UUD 1945 pertama kali disahkan tanggal 18 Agustus 1945. ${ }^{7}$

Pasal 20 Ayat (1) Undang-Undang Dasar Negara Republik Indonesia Tahun 1945 mengatur bahwa Dewan Perwakilan Rakyat memegang kekuasaan membentuk undang-undang. Jika dibandingkan dengan rumusan lama UUD 1945 sebelum amandemen, maka pada prinsipnya dapat dikatakan telah terjadi pergeseran kekuasaan legislatif dari tangan Presiden ke tangan DPR. Bahkan setiap rancangan undang-undang harus dibahas bersama oleh Presiden dan DPR serta harus mendapat persetujuan bersama antara keduanya sebagai syarat untuk dapat disahkan oleh Presiden menjadi undang-undang. Berdasarkan perubahan tersebut, diperlukan undang-undang yang mengatur mengenai pembentukan peraturan perundang-undangan sebagai landasan yuridis dalam membentuk peraturan perundang-undangan baik di tingkat pusat maupun daerah.

Untuk memenuhi perintah Pasal 22 A Undang-Undang Dasar Negara Republik Indonesia Tahun 1945 dan Pasal 6 Ketetapan Majelis Permusyawaratan Rakyat Nomor III/MPR/2000 tentang Sumber Hukum dan Tata Urutan Peraturan Perundang-undangan, diundangkanlah Undang-Undang Nomor 10 Tahun 2004 Tentang Pembentukan Peraturan Perundang-undangan. Selanjutnya, dalam

\footnotetext{
${ }^{7}$ Jimly Asshiddiqie, Komentar Atas Undang-Undang Dasar Negara Republik Indonesia Tahun 1945, (Jakarta:Sinar Grafika, 2009), hal. v-vi
} 
perkembangannya ditemukan beberapa kelemahan dalam UU tersebut hingga akhirnya diganti dengan Undang-Undang Nomor 12 Tahun 2011 Tentang Pembentukan Peraturan Perundang-undangan. Undang-Undang ini merupakan penyempurnaan terhadap kelemahan-kelemahan yang terdapat dalam Undang-Undang Nomor 10 Tahun 2004, yaitu antara lain:

a. Materi dari Undang-Undang Nomor 10 Tahun 2004 banyak yang menimbulkan kerancuan atau multitafsir sehingga tidak memberikan suatu kepastian hukum;

b. teknik penulisan rumusan banyak yang tidak konsisten;

c. terdapat materi baru yang perlu diatur sesuai dengan perkembangan atau kebutuhan hukum dalam pembentukan peraturan perundang-undangan;

d. diinginkannya penguaraian materi sesuai dengan yang diatur dalam tiap bab sesuai dengan sistematika.

Ada materi muatan baru yang ditambahkan dalam Undang-Undang Nomor 12 Tahun 2011 Tentang Pembentukan Peraturan Perundang-undangan ini, yaitu antara lain:

a. penambahan Ketetapan Majelis Permusyawaratan Rakyat sebagai salah satu jenis Peraturan Perundang-undangan dan hierarkinya ditempatkan setelah Undang-Undang Dasar Negara Republik Indonesia Tahun 1945;

b. perluasan cakupan perencanaan Peraturan Perundang-undangan yang tidak hanya untuk Prolegnas dan Prolegda melainkan juga perencanaan Peraturan Pemerintah, Peraturan Presiden, dan Peraturan Perundangundangan lainnya;

c. pengaturan mekanisme pembahasan Rancangan Undang-Undang tentang Pencabutan Peraturan Pemerintah Pengganti Undang-Undang;

d. pengaturan Naskah Akademik sebagai suatu persyaratan dalam penyusunan Rancangan Undang-Undang atau Rancangan Peraturan Daerah Provinsi dan Rancangan Peraturan Daerah Kabupaten/Kota; 
e. pengaturan mengenai keikutsertaan Perancang Peraturan Perundangundangan, peneliti, dan tenaga ahli dalam tahapan Pembentukan Peraturan Perundang-undangan; dan

f. penambahan teknik penyusunan Naskah Akademik dalam Lampiran I Undang-Undang ini.

Undang-Undang Nomor 12 Tahun 2011 Tentang Pembentukan Peraturan Perundang-undangan terdiri dari 104 Pasal, Penjelasan, dan 2 (dua) lampiran. Undang-Undang ini memuat materi-materi pokok yang disusun secara sistematis sebagai berikut:

$\begin{array}{lll}\text { Bab I } & : & \text { Ketentuan Umum } \\ \text { Bab II } & : & \text { Asas Pembentukan Peraturan Perundang-undangan } \\ \text { Bab III } & : & \text { Jenis, Hierarki, dan Materi Muatan Peraturan } \\ & & \text { Perundang-undangan } \\ \text { Bab IV } & : & \text { Perencanaan Peraturan Perundang-undangan } \\ \text { Bab V } & : & \text { Penyusunan Peraturan Perundang-undangan } \\ \text { Bab VI } & : & \text { Teknik Penyusunan Peraturan Perundang-undangan } \\ \text { Bab VII } & : & \text { Pembahasan dan Pengesahan Rancangan Undang-Undang } \\ \text { Bab VIII } & : & \text { Pembahasan dan Penetapan Rancangan Peraturan Daerah } \\ & & \text { Provinsi dan Rancangan Peraturan Daerah Kabupaten/Kota }\end{array}$

Bab IX : Pengundangan

Bab X : Penyebarluasan

Bab XI : Partisipasi

Bab XII : Ketentuan lain-lain

Bab XIII : Ketentuan Penutup

Tahapan perencanaan, penyusunan, pembahasan, pengesahan dan penetapan, serta pengundangan merupakan langkah-langkah dalam Pembentukan Peraturan Perundang-undangan. Namun, tahapan tersebut dilaksanakan sesuai dengan jenis dan hierarki Peraturan Perundang-undangan tertentu yang pembentukannya tidak diatur dengan Undang-Undang ini. Selain itu, juga diadakan penyempurnaan teknik penyusunan Peraturan 
Perundang-undangan beserta contohnya yang ditempatkan dalam Lampiran II untuk memberikan pedoman yang lebih jelas dan pasti yang disertai dengan contoh bagi penyusunan peraturan perundang-undangan, termasuk peraturan perundang-undangan di daerah.

Untuk pembentukan suatu undang-undang, materi muatannya berisi:

a. pengaturan lebih lanjut mengenai ketentuan Undang-Undang Dasar Negara Republik Indonesia Tahun 1945;

b. perintah suatu Undang-Undang untuk diatur dengan Undang-Undang;

c. pengesahan perjanjian internasional tertentu;

d. tindak lanjut atas putusan Mahkamah Konstitusi; dan/atau

e. pemenuhan kebutuhan hukum dalam masyarakat.

Berdasarkan Pasal 5 Undang-Undang Nomor 12 Tahun 2011 Tentang Pembentukan Peraturan Perundang-undangan, dalam membentuk peraturan perundang-undangan harus dilakukan berdasarkan pada asas pembentukan peraturan perundang-undangan yang baik, meliputi:

a. asas kejelasan tujuan, yaitu setiap pembentukan peraturan perundang-undangan harus mempunyai tujuan yang jelas yang hendak dicapai;

b. asas kelembagaan atau pejabat pembentuk yang tepat adalah bahwa setiap jenis peraturan perundang-undangan harus dibuat oleh lembaga negara atau pejabat pembentuk peraturan perundang-undangan yang berwenang. peraturan perundang-undangan tersebut dapat dibatalkan atau batal demi hukum apabila dibuat oleh lembaga negara atau pejabat yang tidak berwenang;

c. asas kesesuaian antara jenis, hierarki, dan materi muatan adalah bahwa dalam pembentukan peraturan perundang-undangan harus benar-benar memperhatikan materi muatan yang tepat sesuai dengan jenis dan hierarki peraturan perundang-undangan;

d. asas dapat dilaksanakan yaitu setiap pembentukan peraturan perundang-undangan harus memperhitungkan efektivitas peraturan 
perundang-undangan tersebut di dalam masyarakat, baik secara filosofis, sosiologis, maupun yuridis;

e. asas kedayagunaan dan kehasilgunaan adalah bahwa setiap peraturan perundang-undangan dibuat karena memang benar-benar dibutuhkan dan bermanfaat dalam mengatur kehidupan bermasyarakat, berbangsa, dan bernegara;

f. asas kejelasan rumusan adalah setiap peraturan perundang-undangan harus memenuhi persyaratan teknis penyusunan peraturan perundang-undangan, sistematika, pilihan kata atau istilah, serta bahasa hukum yang jelas dan mudah dimengerti sehingga tidak menimbulkan berbagai macam interpretasi dalam pelaksanaannya;

g. asas keterbukaan adalah dalam pembentukan peraturan perundang-undangan mulai dari perencanaan, penyusunan, pembahasan, pengesahan atau penetapan, dan pengundangan bersifat transparan dan terbuka. Dengan demikian, seluruh lapisan masyarakat mempunyai kesempatan yang seluas-luasnya untuk memberikan masukan dalam pembentukan peraturan perundang-undangan

Lebih lanjut berdasarkan Pasal 6 ayat (1) Undang-Undang Nomor 12 Tahun 2011 Tentang Pembentukan Peraturan Perundang-undangan, materi muatan peraturan perundang-undangan harus mencerminkan asas-asas sebagai berikut:

a. asas pengayoman adalah bahwa setiap materi muatan peraturan perundang-undangan harus berfungsi memberikan pelindungan untuk menciptakan ketentraman masyarakat;

b. asas kemanusiaan adalah bahwa setiap materi muatan peraturan perundang-undangan harus mencerminkan pelindungan dan penghormatan hak asasi manusia serta harkat dan martabat setiap warga negara dan penduduk Indonesia secara proporsional;

c. asas kebangsaan adalah bahwa setiap materi muatan peraturan perundang-undangan harus mencerminkan sifat dan watak bangsa Indonesia 
yang majemuk dengan tetap menjaga prinsip Negara Kesatuan Republik Indonesia;

d. asas kekeluargaan adalah bahwa setiap materi muatan peraturan perundang-undangan harus mencerminkan musyawarah untuk mencapai mufakat dalam setiap pengambilan keputusan;

e. asas kenusantaraan adalah bahwa setiap materi muatan peraturan perundang-undangan senantiasa memperhatikan kepentingan seluruh wilayah indonesia dan materi muatan peraturan perundang-undangan yang dibuat di daerah merupakan bagian dari sistem hukum nasional yang berdasarkan Pancasila dan Undang-Undang Dasar Negara Republik Indonesia Tahun 1945;

f. asas bhinneka tunggal ika adalah bahwa materi muatan peraturan perundang-undangan harus memperhatikan keragaman penduduk, agama, suku dan golongan, kondisi khusus daerah serta budaya dalam kehidupan bermasyarakat, berbangsa, dan bernegara;

g. asas keadilan adalah bahwa setiap materi muatan peraturan perundang-undangan harus mencerminkan keadilan secara proporsional bagi setiap warga negara;

h. asas kesamaan kedudukan dalam hukum dan pemerintahan adalah bahwa setiap materi muatan peraturan perundang-undangan tidak boleh memuat hal yang bersifat membedakan berdasarkan latar belakang, antara lain, agama, suku, ras, golongan, gender, atau status sosial;

i. asas ketertiban dan kepastian hukum adalah bahwa setiap materi muatan peraturan perundang-undangan harus dapat mewujudkan ketertiban dalam masyarakat melalui jaminan kepastian hukum;

j. asas keseimbangan, keserasian, dan keselarasan” adalah bahwa setiap materi muatan peraturan perundang-undangan harus mencerminkan keseimbangan, keserasian, dan keselarasan, antara kepentingan individu, masyarakat dan kepentingan bangsa dan negara. 
Perencanaan penyusunan undang-undang dilakukan dalam Program Legislasi Nasional (Prolegnas) dalam rangka mewujudkan sistem hukum nasional. Penyusunannya dilakukan DPR bersama pemerintah. Untuk penyusunan undang-undang dimulai dari rancangan undang-undang (RUU) yang dapat berasal dari DPR atau Presiden, maupun dari DPD yang kesemuanya harus disertai Naskah Akademik. Khusus untuk RUU dari DPD adalah RUU yang berkaitan dengan otonomi daerah, hubungan pusat dan daerah, pembentukan dan pemekaran serta penggabungan daerah, pengelolaan sumber daya alam dan sumber daya ekonomi lainnya, dan perimbangan keuangan pusat dan daerah.

RUU dari DPR diajukan oleh anggota DPR, komisi, gabungan komisi, atau alat kelengkapan DPR yang khusus menangani bidang legislasi yang diatur dengan Peraturan DPR. RUU dari DPR disampaikan dengan surat pimpinan DPR kepada Presiden. Presiden menugasi menteri yang mewakili untuk membahas Rancangan Undang-Undang bersama DPR dalam jangka waktu paling lama 60 (enam puluh) hari terhitung sejak surat pimpinan DPR diterima.

RUU dari Presiden disiapkan oleh menteri atau pimpinan lembaga pemerintah nonkementerian sesuai dengan lingkup tugas dan tanggung jawabnya yang diatur dengan Peraturan Presiden. RUU dari Presiden diajukan dengan surat Presiden kepada pimpinan DPR. Surat Presiden memuat penunjukan menteri yang ditugasi mewakili Presiden dalam melakukan pembahasan Rancangan Undang-Undang bersama DPR. DPR mulai membahas Rancangan Undang-Undang sebagaimana dimaksud pada ayat (1) dalam jangka waktu paling lama 60 (enam puluh) hari terhitung sejak surat Presiden diterima.

Pembahasan RUU dilakukan oleh DPR bersama Presiden atau menteri yang ditugasi. Pembahasannya dilakukan melalui 2 (dua) tingkat pembicaraan yang terdiri atas :

a. pembicaraan tingkat I dalam rapat komisi, rapat gabungan komisi, rapat Badan Legislasi, rapat Badan Anggaran, atau rapat Panitia Khusus; dan

b. pembicaraan tingkat II dalam rapat paripurna. 
Pembicaraan tingkat I dilakukan dengan kegiatan sebagai berikut:

a. pengantar musyawarah;

b. pembahasan daftar inventarisasi masalah; dan

c. penyampaian pendapat mini.

Pembicaraan tingkat II merupakan pengambilan keputusan dalam rapat paripurna dengan kegiatan:

a. penyampaian laporan yang berisi proses, pendapat mini fraksi, pendapat mini DPD, dan hasil pembicaraan tingkat I;

b. pernyataan persetujuan atau penolakan dari tiap-tiap fraksi dan anggota secara lisan yang diminta oleh pimpinan rapat paripurna; dan

c. penyampaian pendapat akhir Presiden yang dilakukan oleh menteri yang ditugasi.

Jika RUU tidak mendapat persetujuan bersama antara DPR dan Presiden, RUU tersebut tidak boleh diajukan lagi dalam persidangan DPR masa itu. RUU yang telah disetujui bersama oleh DPR dan Presiden disampaikan oleh Pimpinan DPR kepada Presiden untuk disahkan menjadi Undang-Undang. Penyampaian Rancangan Undang-Undang sebagaimana dimaksud pada ayat (1) dilakukan dalam jangka waktu paling lama 7 (tujuh) hari terhitung sejak tanggal persetujuan bersama. RUU ini disahkan oleh Presiden dengan membubuhkan tanda tangan dalam jangka waktu paling lama 30 (tiga puluh) hari terhitung sejak RUU tersebut disetujui bersama oleh DPR dan Presiden.

Jika RUU itu tidak ditandatangani oleh Presiden dalam waktu paling lama 30 (tiga puluh) hari terhitung sejak RUU tersebut disetujui bersama, RUU tersebut sah menjadi Undang-Undang dan wajib diundangkan dan kalimat pengesahannya tertulis "Undang-Undang ini dinyatakan sah berdasarkan ketentuan Pasal 20 ayat (5) Undang-Undang Dasar Negara Republik Indonesia Tahun 1945". Kalimat pengesahan ini harus dibubuhkan pada halaman terakhir Undang-Undang sebelum pengundangan naskah Undang-Undang ke dalam Lembaran Negara Republik Indonesia. 


\section{Perubahan Terhadap Undang-Undang Perpajakan}

Politik hukum perpajakan yang diterapkan di Indonesia, khususnya dalam hal proses pembentukan peraturan perundang-undangan, sampai saat ini dapat dikelompokkan dalam beberapa periode, yaitu: ${ }^{8}$

1. Periode sebelum reformasi perpajakan, yaitu masa yang terjadi pada tahun 1950 sampai dengan tahun 1982, yaitu penerapan perundang-undangan perpajakan yang masih menggunakan produk Belanda;

2. periode reformasi perpajakan pertama terjadi sejak tahun 1983 sampai dengan tahun 1993 (kurang lebih berlaku selama 10 tahun), yaitu sejak diundangkannya tiga paket UU, yaitu UU No. 6 Tahun 1983, UU No. 7 Tahun 1983, dan UU No. 8 Tahun 1983;

3. periode reformasi perpajakan kedua, terjadi sejak tahun 1994 sampai dengan tahun 1999 (selama kurang lebih 5 tahun), yaitu adanya perubahan perundang-undangan dari tiga paket UU di atas menjadi UU No. 9 Tahun 1994, UU No. 10 Tahun 1994, dan UU No. 11 Tahun 1994;

4. periode reformasi perpajakan ketiga, terjadi sejak tahun 2000 sampai dengan tahun 2007 (selama kurang lebih 7 tahun), yaitu adanya perubahan perundang-undangan dari tiga paket UU di atas menjadi UU No. 16 tahun 2000, UU No. 17 Tahun 2000, dan UU No. 18 Tahun 2000;

5. periode reformasi perpajakan keempat terjadi sejak tahun 2007 sampai sekarang, yaitu adanya perubahan perundang-undangan dari tiga paket UU di atas. Sejak tahun 2007 sampai dengan tahun 2010, telah dilakukan perubahan tiga paket UU Perpajakan, yaitu UU No. 28 Tahun 2007 Tentang Perubahan Ketiga atas UU No. 6 Tahun 1983, UU No. 36 Tahun 2008 Tentang Perubahan Keempat atas UU No. 7 Tahun 1983 Tentang Pajak Penghasilan, dan UU No. 42 Tahun 2009 tentang Perubahan Ketiga atas UU No. 8 tahun 1983 Tentang Pajak Pertambahan Nilai dan Pajak Penjualan atas Barang Mewah.

\footnotetext{
${ }^{8}$ Wirawan B. Ilyas dan Richard Burton, Hukum Pajak Edisi 5, (Jakarta: Salemba Empat, 2011), hal. 17-18
} 
Pajak Pertambahan Nilai mulai berlaku di Indonesia sejak 1 April 1985 berdasarkan UU Nomor 8 tahun 1983. Berdasarkan Pasal 21, UU ini ditentukan mulai berlaku sejak 1 Juli 1984. Dengan Peraturan Pemerintah Pengganti Undang-Undang Nomor 1 tahun 1984, saat berlaku UU ini ditunda sampai dengan selambat-lambatnya awal tahun 1986. Kemudian dengan Peraturan Pemerintah Nomor 1 tahun 1985, undang-undang ini ditetapkan mulai berlaku sejak 1 April 1985. UU ini telah tiga kali mengalami perubahan, yakni:

1. mulai 1 januari 1995 dilakukan perubahan I dengan Undang-Undang Nomor 11 Tahun 1994 Tentang Perubahan Pertama Atas Undang-Undang Nomor 8 Tahun 1983 Tentang Pajak Pertambahan Nilai dan Pajak Penjualan atas Barang Mewah, meliputi Pasal 1 sampai dengan Pasal 17;

2. mulai 1 Januari 2001 dilakukan perubahan II dengan Undang-Undang Nomor 18 Tahun 2000 Tentang Perubahan Kedua Atas Undang-Undang Nomor 8 Tahun 1983 Tentang Pajak Pertambahan Nilai dan Pajak Penjualan atas Barang Mewah, meliputi Pasal 1 sampai dengan Pasal 16 C;

3. mulai 1 April 2010 dilakukan perubahan III dengan Undang-Undang Nomor 42 Tahun 2009 Tentang Perubahan Ketiga Atas Undang-Undang Nomor 8 Tahun 1983 Tentang Pajak Pertambahan Nilai dan Pajak Penjualan atas Barang Mewah, meliputi Pasal 1 sampai dengan Pasal 16 D.

Menurut Untung Sukardji, meskipun sudah tiga kali diubah, nama UU Nomor 8 Tahun 1983 tidak mengalami perubahan, berarti namanya tetap "UU Pajak Pertambahan Nilai 1984" karena: ${ }^{9}$

1. Dari tiga kali perubahan ternyata tidak pernah mengubah Pasal 20. Padahal dalam pasal ini ditentukan bahwa nama UU Nomor 8 Tahun 1983 adalah UU PPN 1984;

2. Baik UU Nomor 11 Tahun 1994 maupun UU Nomor 18 Tahun 2000 tidak pernah menggantikan kedudukan UU Nomor 8 Tahun 1983. Hal ini dapat disimak bunyinya:

\footnotetext{
${ }^{9}$ Untung Sukardji, Undang-Undang PPN 1984 Setelah Perubahan Ketiga Dengan Undang-Undang
} Nomor 42 tahun 2009:Komentar Pasal Demi Pasal, (Jakarta: PT Raja Grafindo Persada, 2010), hal. 21-22 
a) Pasal III UU Nomor 11 Tahun 1994: “Undang-undang ini dapat disebut Undang-Undang Perubahan Undang-Undang Pajak Pertambahan Nilai 1984”. Jadi undang-undang ini tidak pernah menyatakan namanya adalah UU PPN 1994.

b) Pasal II UU Nomor 18 Tahun 2000: "Undang-undang ini dapat disebut Undang-Undang Perubahan Kedua Undang-Undang Pajak Pertambahan Nilai 1984". Jadi, undang-undang ini tidak pernah menyatakan namanya adalah UU PPN 2000.

3. Adapun UU Nomor 42 Tahun 2009 tidak menetapkan nama dari undang-undang ini. Hal ini bukan berarti bahwa UU Nomor 42 Tahun 2009 menjadi UU PPN 2009, karena dalam perubahan ketiga selain tidak mengubah Pasal 20 UU Nomor 8 Tahun 1983, juga tidak mencabut eksistensi UU Nomor 8 Tahun 1983 sehingga sama halnya dengan undang-undang tentang perubahan sebelumnya, undang-undang ini tidak menggantikan kedudukan UU Nomor 8 Tahun 1983. Kesimpulannya tidak pernah ada UU PPN Tahun 1994 atau UU PPN 2000 dan tidak akan ada UU PPN Tahun 2009.

Selain UU PPN, terdapat UU lain di bidang perpajakan yang telah mengalami perubahan beberapa kali, yaitu undang-undang yang mengatur tentang ketentuan umum dan tata cara perpajakan yang lebih dikenal dengan singkatan UU KUP. Undang-undang ini telah mengalami 4 (empat) kali perubahan sebagai berikut:

1. Pertama kalinya UU ini diatur melalui Undang-Undang Nomor 6 Tahun 1983 Tentang Ketentuan Umum dan Tata Cara Perpajakan;

2. selanjutnya mengalami perubahan menjadi Undang-Undang Nomor 9 Tahun 1994 Tentang Perubahan Pertama Atas Undang-Undang Nomor 6 Tahun 1983 Tentang Ketentuan Umum dan Tata Cara Perpajakan. UU ini tidak mengubah semua pasal dan mulai berlaku pada tanggal 1 Januari 1995.

3. kemudian diubah menjadi Undang-Undang Nomor 16 Tahun 2000 Tentang Perubahan Kedua Atas Undang-Undang Nomor 6 Tahun 1983 Tentang 
Ketentuan Umum dan Tata Cara Perpajakan, meliputi Pasal 1 sampai dengan Pasal 47. UU mulai berlaku pada tanggal 1 Januari 2001;

4. sejak 1 Januari 2008, menjadi Undang-Undang Nomor 28 Tahun 2007 Tentang Perubahan Ketiga Atas Undang-Undang Nomor 6 Tahun 1983 Tentang Ketentuan Umum dan Tata Cara Perpajakan, meliputi Pasal 1 sampai dengan Pasal 44 B;

5. tidak lama setelah itu pada tahun 2008 dikeluarkan Peraturan Pemerintah Pengganti Undang-Undang Nomor 5 Tahun 2008 yang mengubah satu pasal khususnya Pasal 44 ayat (3). PERPU ini ditetapkan menjadi Undang-Undang Nomor 16 Tahun 2009 Tentang Penetapan Peraturan Pemerintah Pengganti Undang-Undang Nomor 5 Tahun 2008 Tentang Perubahan Keempat Atas Undang-Undang Nomor 6 Tahun 1983 Tentang Ketentuan Umum dan Tata Cara Perpajakan.

Undang-undang di bidang perpajakan lainnya yang banyak mengalami perubahan adalah undang-undang yang mengatur tentang pajak penghasilan atau yang lebih dikenal dengan UU PPh. Peraturan ini telah mengalami perubahan sebagai berikut:

1. Pertama kalinya UU ini diatur melalui Undang-Undang Nomor 7 Tahun 1983 Tentang Pajak Penghasilan;

2. kemudian diubah menjadi Undang-Undang Nomor 10 Tahun 1994 Tentang Perubahan Pertama Atas Undang-Undang Nomor 7 Tahun 1983 Tentang Pajak Penghasilan, meliputi Pasal 1 sampai dengan Pasal 35;

3. melalui reformasi perpajakan tahun 2000, diubah menjadi Undang-Undang Nomor 17 Tahun 2000 Tentang Perubahan Kedua Atas Undang-Undang Nomor 7 Tahun 1983 Tentang Pajak Penghasilan meliputi Pasal 1 sampai dengan Pasal 31 E;

4. lama tidak mengalami perubahan, pada tahun 2008 mengalami perubahan menjadi Undang-Undang Nomor 36 Tahun 2008 Tentang Perubahan Ketiga Atas Undang-Undang Nomor 7 Tahun 1983 Tentang Pajak Penghasilan meliputi Pasal 2 sampai dengan Pasal 35. 
Perbedaannya dengan UU PPN adalah sejak awal UU KUP dan UU PPh diundangkan tidak ada pasal yang mengatur tentang penyebutan nama dari UU tersebut. Oleh karena itu, ketika para pihak hendak menggunakan UU KUP dan UU PPh dapat menggunakan penyebutan atau nama dari tahun ketika UU tersebut terakhir diundangkan untuk memudahkan penyebutannya saja. Setelah diteliti, perubahan terhadap undang-undang tersebut ternyata perubahan meliputi seluruh pasalnya, baik hanya menyisipkan atau menambah materi ke dalam peraturan perundang-undangan bahkan menghapus atau mengganti sebagian materi peraturan perundang-undangan.

\section{Pembatasan Frasa Perubahan Kesekian Kali Pada Perumusan Judul Undang-Undang}

Perubahan suatu peraturan perundang-undangan dilakukan apabila terdapat ketentuan-ketentuan dalam peraturan perundang-undangan tersebut yang tidak sesuai lagi dengan situasi atau kondisi yang berlaku dalam masyarakat. Dalam mengadakan perubahan terhadap suatu peraturan perundang-undangan, hal-hal yang harus diperhatikan adalah sebagai berikut: ${ }^{10}$

a. Perubahan suatu peraturan perundang-undangan dilakukan oleh pejabat yang berwenang membentuknya, berdasarkan pada prosedur yang berlaku, dan dengan suatu peraturan perundang-undangan yang sejenis (atau setingkat);

b. perubahan suatu peraturan perundang-undangan diharapkan dilakukan secara baik tanpa mengubah sistematika dari peraturan perundang-undangan yang diubah;

c. dalam suatu peraturan perubahan, perumusan judul hendaknya disebut peraturan perundang-undangan mana yang diubah dan untuk perubahan yang kedua kali dan selanjutnya disebutkan dengan jelas perubahan yang ke berapa kalinya;

\footnotetext{
${ }^{10}$ Maria Farida Indrati, Ilmu Perundang-undangan Jilid II, (Yogyakarta: Kanisius, 2007), hal. 179-180
} 
d. dalam konsiderans dari peraturan perundang-undangan yang diubah harus dikemukakan alasan-alasan atau pertimbangan-pertimbangan lainnya mengapa peraturan yang lama perlu diadakan perubahan;

e. batang tubuh suatu peraturan perundang-undangan yang diubah hanya terdiri atas dua pasal yang ditulis dengan angka Romawi. Dalam kedua pasal tersebut dimuat ketentuan sebagai berikut:

1) Pasal I memuat segala sesuatu perubahan, dengan diawali penyebutan peraturan perundang-undangan yang diubah, dan urutan perubahanperubahan tersebut hendaknya ditulis dengan angka Arab 1,2,3, dan selanjutnya.

2) Pasal II memuat ketentuan mengenai berlakunya peraturan perubahan tersebut.

f. apabila suatu peraturan perundang-undangan sudah mengalami perubahan berulang kali, maka sebaiknya peraturan perundang-undangan tersebut dicabut dan diganti dengan peraturan perundang-undangan yang baru;

g. apabila pembuat peraturan perundang-undangan berniat mengubah secara besar-besaran, maka demi kepentingan pemakai peraturan perundangundangan tersebut dipandang lebih baik apabila dibentuk peraturan perundang-undangan yang baru.

Perubahan terhadap suatu peraturan perundang-undangan diatur dalam Undang-Undang Nomor 12 Tahun 2011 Tentang Pembentukan Peraturan Perundang-undangan, Lampiran II Teknik Penyusunan Peraturan Perundang-undangan Nomor 230-238 sebagai berikut: ${ }^{11}$

1. Perubahan Peraturan Perundang-undangan dapat dilakukan dengan:

a. menyisip atau menambah materi ke dalam Peraturan Perundangundangan

b. menghapus atau mengganti sebagian materi Peraturan Perundangundangan.

\footnotetext{
${ }^{11}$ Indonesia, Undang-Undang Pembentukan Peraturan Perundang-undangan, UU No. 12 Tahun 2011, Lampiran II Teknik Penyusunan Peraturan Perundang-undangan Nomor 230-238
} 
2. Perubahan Peraturan Perundang-undangan dapat dilakukan terhadap:

a. seluruh atau sebagian buku, bab, bagian, paragraf, pasal, dan/atau ayat; atau

b. kata, frasa, istilah, kalimat, angka, dan/atau tanda baca.

3. Jika Peraturan Perundang-undangan yang diubah mempunyai nama singkat, Peraturan Perundang-undangan perubahan dapat menggunakan nama singkat Peraturan Perundang-undangan yang diubah.

4. Pada dasarnya batang tubuh Peraturan Perundang-undangan perubahan terdiri atas 2 (dua) pasal yang ditulis dengan angka Romawi yaitu sebagai berikut:

a) Pasal I memuat judul Peraturan Perundang-undangan yang diubah, dengan menyebutkan Lembaran Negara Republik Indonesia dan Tambahan Lembaran Negara Republik Indonesia yang diletakkan di antara tanda baca kurung serta memuat materi atau norma yang diubah. Jika materi perubahan lebih dari satu, setiap materi perubahan dirinci dengan menggunakan angka Arab (1, 2, 3, dan seterusnya).

b) Jika peraturan perundang-undangan telah diubah lebih dari satu kali, Pasal I memuat, selain mengikuti ketentuan pada Nomor 233 huruf a, juga tahun dan nomor dari peraturan perundang-undangan perubahan yang ada serta lembaran negara Republik Indonesia dan Tambahan Lembaran Negara Republik Indonesia yang diletakkan di antar tanda baca kurung dan dirinci dengan huruf (abjad) kecil (a,b,c, dan seterusnya).

c) Pasal II memuat ketentuan tentang saat mulai berlaku. Dalam hal tertentu, Pasal II juga dapat memuat ketentuan peralihan dari peraturan perundangan-undangan perubahan, yang maksudnya berbeda dengan ketentuan peralihan dari peraturan perundang-undangan yang diubah.

5. Jika dalam Peraturan Perundang-undangan ditambahkan atau disisipkan bab, bagian, paragraf, atau pasal baru, maka bab, bagian, paragraf, atau pasal baru tersebut dicantumkan pada tempat yang sesuai dengan materi yang bersangkutan. 
6. Jika dalam 1 (satu) pasal yang terdiri dari beberapa ayat disisipkan ayat baru, penulisan ayat baru tersebut diawali dengan angka Arab sesuai dengan angka ayat yang disisipkan dan ditambah dengan huruf kecil a, b, c, yang diletakkan di antara tanda baca kurung( ).

7. Jika dalam suatu Peraturan Perundang-undangan dilakukan penghapusan atas suatu bab, bagian, paragraf, pasal, atau ayat, maka urutan bab, bagian, paragraf, pasal, atau ayat tersebut tetap dicantumkan dengan diberi keterangan dihapus.

8. Jika suatu perubahan Peraturan Perundang-undangan mengakibatkan:

a. sistematika Peraturan Perundang-undangan berubah;

b. materi Peraturan Perundang-undangan berubah lebih dari 50\% (lima puluh persen); atau

c. esensinya berubah

Peraturan Perundang-undangan yang diubah tersebut lebih baik dicabut dan disusun kembali dalam Peraturan Perundang-undangan yang baru mengenai masalah tersebut.

9. Jika suatu Peraturan Perundang-undangan telah sering mengalami perubahan sehingga menyulitkan pengguna Peraturan Perundangundangan, sebaiknya Peraturan Perundang-undangan tersebut disusun kembali dalam naskah sesuai dengan perubahan yang telah dilakukan, dengan mengadakan penyesuaian pada: urutan bab, bagian, paragraf, pasal, ayat, angka, atau butir; penyebutan-penyebutan; dan ejaan, jika Peraturan Perundang-undangan yang diubah masih tertulis dalam ejaan lama.

Menurut Maria Farida, walaupun dimungkinkan adanya perubahan terhadap suatu peraturan perundang-undangan, akan tetapi apabila perubahan tersebut mengakibatkan:

a. sistematika peraturan perundang-undangan yang lama menjadi berubah;

b. materi peraturan berubah:

1) lebih dari $50 \%$ (lima puluh persen), atau

2) esensinya, 
maka peraturan perundang-undangan yang diubah tersebut lebih baik dicabut dan disusun kembali dalam peraturan perundang-undangan yang baru mengenai masalah tersebut. ${ }^{12}$

Maria Farida juga menambahkan, apabila suatu perundang-undangan telah sering mengalami perubahan sehingga menyulitkan pengguna peraturan perundang-undangan tersebut, sebaiknya peraturan perundang-undangan tersebut diumumkan kembali menurut bunyi yang baru sesuai dengan perubahan-perubahan yang telah dilakukan dengan mengadakan penyesuaian pada: ${ }^{13}$

1) urutan bab, bagian, paragraf, pasal, ayat, angka, atau butir;

2) penyebutan-penyebutan; dan

3) ejaan, jika peraturan perundang-undangan yang diubah masih tertulis dalam ejaan lama.

Perubahan yang dilakukan beberapa kali terhadap peraturan di bidang perpajakan sebenarnya dapat dipahami dengan alasan transaksi ekonomi yang berlangsung dengan pesatnya. Namun demikian, jika hal ini terjadi di semua bidang selain perpajakan, maka sebaiknya dapat dilakukan pengaturan tentang pembatasan frasa perubahan kesekian kali pada perumusan judul suatu undang-undang. Penyesuaian dan pengumuman kembali judul undang-undang tersebut dilakukan agar undang-undang tersebut lebih mudah diketahui masyarakat. Ketentuan ini hendaknya juga berlaku terhadap perundang-undangan lainnya yang hierarkinya terletak di bawah undang-undang. Pembatasan pada frasa perubahan kesekian kali pada perumusan judul suatu undang-undang yang telah mengalami beberapa kali perubahan, selain demi kepentingan pengguna undang-undang tersebut sekaligus juga untuk kepastian hukum. Hal ini sesuai dengan Pasal 6 ayat (1) Undang-Undang Nomor 12 Tahun 2011 Tentang Pembentukan Peraturan Perundang-undangan, materi muatan peraturan perundang-undangan harus mencerminkan asas ketertiban dan kepastian hukum.

${ }^{12}$ Maria Farida Indrati, Op.Cit, hal. 181

${ }^{13} \mathrm{Ibid}$, hal 181 
Maksudnya adalah bahwa setiap materi muatan peraturan perundang-undangan harus dapat mewujudkan ketertiban dalam masyarakat melalui jaminan kepastian hukum. Diperlukannya aturan pembatasan tersebut sekaligus sebagai pedoman atau acuan bagi pembuat undang-undang di sini khususnya tenaga perancang peraturan perundang-undangan.

\section{PENUTUP}

\section{Kesimpulan}

Berdasarkan uraian di atas, dapat dikemukakan bahwa apabila perubahan suatu undang-undang mengakibatkan sistematika peraturan perundang-undangan yang lama menjadi berubah dan materi peraturan berubah lebih dari 50\% (lima puluh persen) berikut esensinya, maka undang-undang tersebut sebaiknya dicabut dan disusun kembali. Apabila suatu perundang-undangan telah sering mengalami perubahan sehingga menyulitkan pengguna peraturan perundang-undangan tersebut, sebaiknya peraturan perundang-undangan tersebut diumumkan kembali menurut bunyi yang baru sesuai dengan perubahan-perubahan yang telah dilakukan dengan mengadakan penyesuaian.

\section{Saran}

Sebaiknya dapat dilakukan pengaturan tentang pembatasan frasa perubahan kesekian kali pada perumusan judul suatu undang-undang dalam undang-undang tentang pembentukan peraturan perundangan-undangan sehingga hal ini juga dapat berlaku terhadap peraturan lain di bawah undang-undang.

\section{DAFTAR PUSTAKA}

Asshiddiqie, Jimly, 2009. Komentar Atas Undang-Undang Dasar Negara Republik Indonesia Tahun 1945, Jakarta:Sinar Grafika.

Fidel, 2007. Pembahasan Undang-Undang Nomor 28 Tahun 2007 Tentang Ketentuan Umum dan Tata Cara Perpajakan, Jakarta: Amparo's Publishing.

Ilyas, Wirawan B, Richard Burton, 2011. Hukum Pajak Edisi 5, Jakarta: Salemba Empat 
Indrati, Maria Farida, 2007. Ilmu Perundang-undangan Jilid I dan II, Yogyakarta: Kanisius.

Marzuki, Peter Mahmud, 2009. Pengantar Ilmu Hukum, Jakarta: Kencana Prenada Media Grup.

Mertokusumo, Sudikno, 2010. Penemuan Hukum, Yogyakarta: Universitas Atmajaya.

Soekanto, Soerjono, Sri Mamudji, 2001. Penelitian Hukum Normatif Suatu Tinjauan Singkat, Jakarta: PT Raja Grafindo Persada.

Sukardji, Untung, 2010. Undang-Undang PPN 1984 Setelah Perubahan Ketiga Dengan Undang-Undang Nomor 42 tahun 2009:Komentar Pasal Demi Pasal, Jakarta: PT Raja Grafindo Persada.

Undang-Undang Nomor 12 Tahun 2011 Tentang Pembentukan Peraturan Perundang-Undangan.

Undang-Undang Nomor 42 Tahun 2009 Tentang Perubahan Ketiga Atas.

Undang-Undang Nomor 8 Tahun 1983 Tentang Pajak Pertambahan Nilai dan Pajak Penjualan atas Barang Mewah.

Undang-Undang Nomor 28 Tahun 2007 Tentang Perubahan Ketiga Atas UndangUndang Nomor 6 Tahun 1983 Tentang Ketentuan Umum dan Tata Cara Perpajakan.

Undang-Undang Nomor 36 Tahun 2008 Tentang Perubahan Ketiga Atas Undang Undang Nomor 7 Tahun 1983 Tentang Pajak Penghasilan. 